\title{
IMPLEMENTASI TEORI PERS TANGGUNG JAWAB SOSIAL DALAM PEMBERITAAN TVRI PUSAT
}

\author{
MADRID DE FRETES \& RETOR A.W. KALIGIS
}

\author{
Fakultas Ilmu Komunikasi Universitas Pancasila \\ Jln Srengseng Sawah Jagakarsa Jakarta Selatan 12640 \\ Email: retor_awk@yahoo.com
}

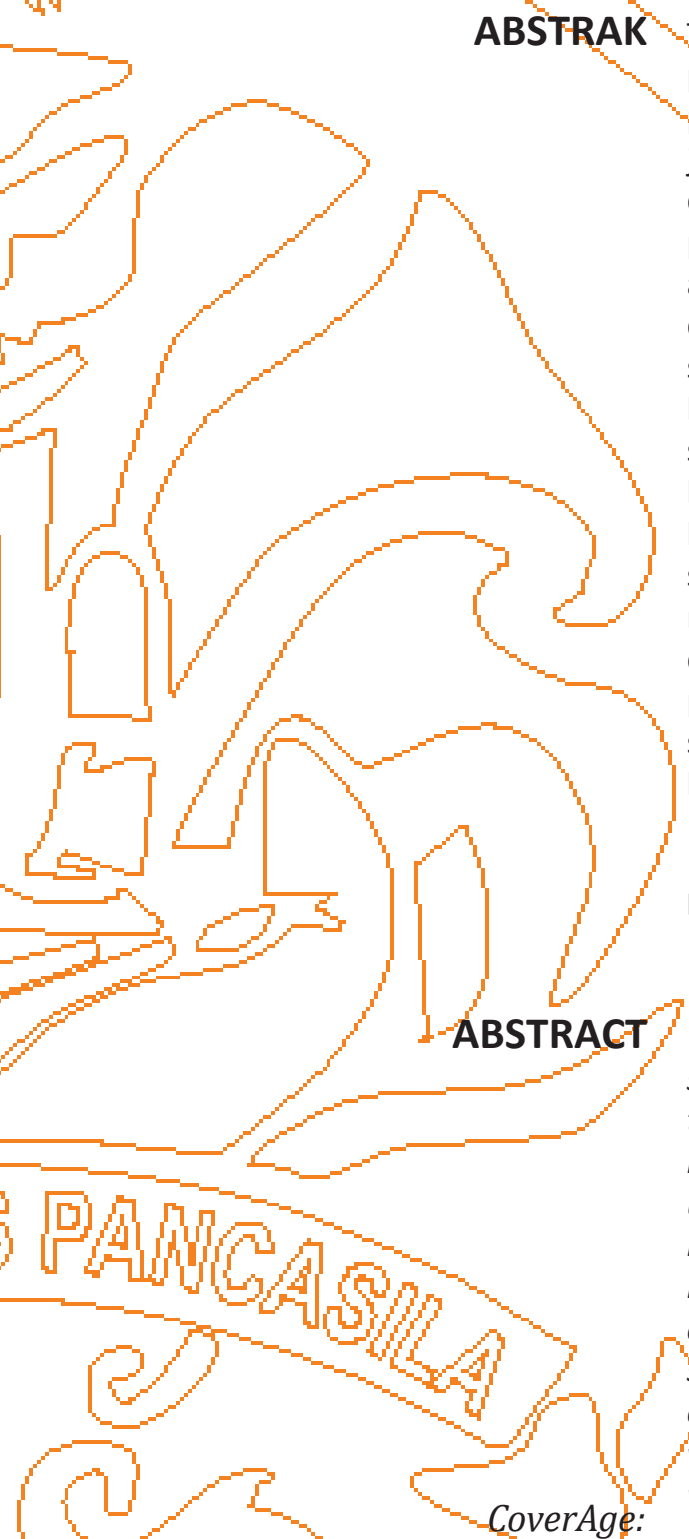

Journal of Strategic

Communication

Vol. 9, No. 1, Hal. 26-34.

September 2018

Fakultas Ilmu Komunikasi, Universitas Pancasila

Diterima 12 Juli 2018

Disetujui 3 September 2018
Tujuan dari penulisan penelitian ini adalah untuk mengetahui implementasi teori pers tanggung jawab sosial dalam pemberitaan TVRI Pusat. Dalam penelitian ini, penulis hanya berfokus pada bentuk-bentuk implementasi teori pers tanggung jawab sosial yang dijalankan dalam pemberitaan. Teknik pengumpulan data yang digunakan yaitu observasi, wawancara dan dokumentasi. Teori yang dipakai dalam penelitian ini ada Teori Tanggung Jawab Sosial Pers, dan konsep yang digunakan adalah TVRI sebagai lembaga layanan publik. Dari temuan yang ada dapat disimpulkan ada beberapa indikator yang menjadi prinsip utama tanggung jawab sosial yang sudah dijalankan oleh TVRI sendiri yaitu menerima dan memenuhi kewajiban kepada masyarakat, memberikan ruang bagi masyarakat menyampaikan sudut pandang sebagi bentuk kontrol masyarakat untuk membangun TVRI yang lebih baik, menghindari pemberitaan yang dapat memecah belah persatuan dan kesatuan, namun TVRI sejauh ini belum mampu untuk mengelola lembaganya secara mandiri tanpa ada intervensi politik karena aturan-aturan yang ada membatas ruang gerak TVRI. Dalam pemberitaan yang membenturkan masyarakat dan pemerintah TVRI belum bisa menyajikan informasi yang netral karena faktor pemerintah sebagai bentuk interpretasi negara sehingga TVRI mengambil posisi sebagai media yang menyajikan pemberitaan yang tidak menjadi kontrol terhadap kekuasaan.

Kata Kunci: Teori pers tanggung jawab sosial, lembaga layanan publik, TVRI.

The purpose of writing this research is to find out how the implementation of social responsibility press theory in the coverage of Central TVRI. In this study, the author only focuses on the forms of implementation of the theory of social responsibility press which are carried out in the news. Data collection techniques used are observation, interview and documentation. The theory used in this study is the Social Responsibility Theory of the Press, and the concepts used are mass media, television, and TVRI as public service partners. From the findings, it can be concluded that there are a number of indicators that are the main principles of social responsibility that TVRI has implemented, namely accepting and fulfilling obligations to the community, providing space for the community to convey a viewpoint as a form of community control to build a better TVRI, avoid reporting which can divide unity and unity, but TVRI has so far not been able to manage its institutions independently without any political intervention because the existing regulations limit the space for TVRI. In the news that hit the public and the government TVRI could not present information that was neutral because of government factors as a form of interpretation of the country so that TVRI took a position as a media that presented news that did not become a control of power.

Keywords: Press theory of social responsibility, the public service institutions, TVRI. 


\section{PENDAHULUAN}

Melalui program berita yang diproduksi, TVRI berupaya menyajikan informasi yang dibutuhkan oleh masyarakat melalui berita yang akurat, berimbang, dan dapat dipercaya. Semua itu sebagai bentuk tanggung jawab kepada masyarakat dan dalam statusnya sebagai lembaga penyiaran publik. Namun, ada beberapa hal yang cukup menyita perhatian, yaitu peristiwa yang terjadi di tahun 2013 silam tepatnya di bulan November, KPI menemukan pelanggaran yang dilakukan oleh TVRI dan sanksi yang diberikan oleh KPI berupa teguran tertulis kepada TVRI karena telah menyiarkan konvensi Partai Demokrat pada Ahad lalu. Menurut penuturan Rahmat Arifin, selaku Ketua Bidang Pengawasan Isi Siaran KPI, Jumat, 20 September 2013 "TVRI terbukti telah melanggar asas netralitas dan independensi," (www.tempo.com).

Hal ini menjadi perhatian karena TVRI sebagai LPP dalam setiap pemberitaanya harus mengacu pada undang-undang penyiaran. Di poin tersebut mengharuskan TVRI harus bersifat independen, netral, tidak komersial, dan berfungsi memberikan layanan untuk kepentingan masyarakat.

Kasus yang lainnya juga sempat terjadi pada salah satu program jurnalitik TVRI yang diproduksi oleh divisi Current Affairs belum lama ini mendapatkan surat teguran KPI (Komisi Penyiaran Indonesia) yang dilayangkan kepada TVRI Pusat pada tanggal 6 Agustus 2018, yang tertulis untuk program jurnalistik "Indonesia Hari Ini" Berdasarkan pemantauan dan hasil analisis, KPI Pusat telah menemukan pelanggaran pada program jurnalistik karena menampilkan visualisasi seorang pria mengonsumsi obat-obat terlarang berupa sabu-sabu.

Walaupun sebelumnya sudah dilakukan upaya penyamaran, namun visualisasi konsumsi tersebut bocor dan masih tampak/terlihat dengan jelas ditayangkan oleh stasiun TVRI, pada tanggal 19 Juli 2018 mulai pukul 16.09 WIB. Akibatnya, TVRI dianggap melanggar Pedoman Perilaku Penyiaran Komisi Penyiaran Indonesia Tahun 2012 Pasal 18 serta Standar Program Siaran Komisi Penyiaran Indonesia Tahun 2012 Pasal 26 Ayat (2) (www. kpi.go.id). Walaupun hanya berupa teguran tertulis namun dari peristiwa ini TVRI di anggap lalai dalam menjalankan tanggung jawab sosial.

Teori pers tanggung jawab sosial perlu dilihat dalam lembaga penyiaran ini karena ditemukan kasus konvensi yang telah dijelaskan di atas, seperti yang diketahui bahwa TVRI memiliki tanggung jawab terhadap kepentingan publik namun kasus yang ditemukan menggambarkan bahwa apa yang terjadi tidak sesuai dengan teori tanggung jawab sosial. Di mana seharusnya lembaga ini memberi pemberitaan yang bermanfaat kepada masyarakat dan bukan kepada kepentingan kalangan elit politik.

Kehadiran pers sangat dibutuhkan untuk mengawasi setiap gerak-gerik pemerintah supaya pemerintah lebih terbuka atau transparan kepada publik dan sekaligus sebagai penghubung antara pemerintah dengan publik, bisa dikatakan posisi pers di sini sebagai komunikator bagi pemerintah. Fungsi pers sebagaimana yang digambarkan yaitu sebagai jembatan ataupun sebagai penghubung antara masyarakat dan pemerintah jika fenomena ini dihubungkan dengan realitas pers yang ada di Indonesia, maka terlihat jelas hubungan segitiga antara pers, masyarakat, dan pemerintah ini belum benar-benar menggambarkan suatu hubungan yang ideal (tirto.id).

Kehadiran TVRI sebagai lembaga penyiaran publik (LPP) tentu menjadi beban tersendiri dalam mengelolah lembaga ini, karena harus menjadi contoh bagi stasiun televisi lain, dengan menjalankan tanggungjawab yang lebih berat dalam prinisp harus menjunjung tinggi netralitas dan keberimbangan dalam memberikan setiap informasi penting bagi masyarakat bila dibandingkan dengan lembaga penyiaran lain.

\section{TINJAUAN PUSTAKA}

\section{Teori Pers Tanggung Jawab Sosial}

Kemunculan teori pers tanggung jawab sosial berawal dari pengembangan teori sebelumnya yaitu teori liberal, yang kala itu di anggap telah gagal untuk menempati janji dalam penggunaan kebebasan pers secara bertanggung jawab. Teori tanggung jawab sosial mulai dipulikasikan oleh Fred Siebert dan temantemannya melalui buku yang berjudul "Four Theory of The Press". Empat teori yang dimaksud antara lain: Teori Otoriter, Teori Liberal, Teori Tanggung jawab Sosial, dan yang terakhir Teori Otoriter Sosialis Komunis.

Teori tanggung jawab sosial seperti yang dibahas sebelumnya itu lahir dari rasa ketidak nyamanan terhadap kebebasan yang sangat berlebihan yang ada pada teori pers liberal. Masalah ini bermula pada abad yang ke-20, di 
mana pada saat itu teori liberal sebagai pemegang kekuasaan. Namun, kekuasaan berupa kebebasan pers yang diberikan disalah gunakan dan menjadi tidak bertanggungjawab.

Biasanya teori tanggung jawab sosial diterapkan di negara- negara yang menganut sistem demokrasi salah satunya adalah negara Indonesia Teori tanggung jawab sosial menganggap bahwa di dalam kebebasan mengandung yang namanya suatu tanggung jawab yang sama. Kelebihan dari teori ini yaitu masyarakat juga memiliki tanggung jawab dalam kebebasannya, sehingga dengan adanya kebebasan ini diharapkan dapat meminimalkan adanya keretakan dalam sebuah negara, dan setiap individu memiliki hak yang sama dengan pemerintah.

Selain memiliki kelebihan, teori ini juga memiliki kelemahan yang salah satunya yaitu penyalahgunaan tanggung jawab untuk sebuah kepentingan, yang di mana pemerintah kemudian bisa menggunakan lembaga atau organisasi yang megontrol sistem penyiaran sebagai alat untuk mencapai kepentingannya (AL-Ahmed,1987:9-20). Menurut Bittner (1989), dalam kebebasan pers yang dimiliki dalam teori ini memberikan peluang kepada pers untuk mengkritik pemerintah beserta institusinya, selain itu memiliki tanggung jawab dasar menjaga stabilitas dalam masyarakat. Bentuk dari tanggung jawab sosial pers yaitu melayani masyarakat, pemberitaan yang bertanggung jawab sosial sebagai bentuk kewajiban pemberitaan itu sendiri pada masyarakat.

Mulai masuk sejak era reformasi, yang pada saat itu sistem politik di Indonesia mulai menggunakan UU no. 40 tahun 1999, maka sejak saat itulah pers di Indonesia mulai menganut teori pers tanggung jawab sosial atau kebebasan pers yang bertanggung jawab kepada publik atau kepentingan umum (Hutagalung, 2013:57)

\section{Ciri-Ciri Teori Pers Tanggung Jawab Sosial}

Adapun beberapa ciri-ciri dari teori pers tanggung jawab sosial yang menjadi prinsip utama (McQuail, 2010: 171-172), yaitu :

1. Media mau menerima dan memenuhi kewajiban dalam masyarakat.

2. Kewajiban dipenuhi dengan standar yang tinggi atau profesionalitas tentang keinformasian, kebenaran, ketepatan, objektivitas, dan juga keseimbangan.

3. Media sudah harus mandiri dalam hal mengatur diri sendiri di dalam kerangka hukum serta lembaga yang ada.
4. Media sebaiknya menghindari segala hal yang dapat menimbulkan kejahatan, kerusakan, atau ketidak tertiban umum atau penghinaan terhadap kaum minoritas etnik maupun juga agama.

5. Media hendaknya bersifat pluralis dan mencerminkan kebinekaan, dengan memberikan kesempatam untuk mengungkapkan berbagai sudut pandang dan hak untuk menjawab.

6. Masyarakat memiliki hak untuk mengharapkan standar prestasi yang tinggi dan profesionalitas mengutamakan kepentingan bersama.

\section{TVRI Sebagai Lembaga Layanan Publik}

Televisi Republik Indonesia (TVRI) merupakan stasiun televisi pertama di Indonesia dan melalui Undang-Undang Republik Indonesia Nomor. 32 tahun 2002 tentang Penyiaran, TVRI ditetapkan sebagai Lembaga Penyiaran Publik yang berbentuk badan hukum yang didirikan oleh negara. Menurut Chris Hanretty, tujuan dari lembaga penyiaran publik yaitu menyediakan konten yang luas serta berguna secara sosial, dan sumber pendapatan pengelolaan lembaga diperoleh dari negara melalui penerimaanpajak umum atau melalui pajak siaran, yang menjadi fokus utamanya menyediakan siaran kepada masyarakat dan berada pada pos tertinggi dari penyiaran ditunjukan oleh badan negara (Hanretty, 2011:4).

TVRI memiliki tugas sebagai televisi yang mengangkat citra bangsa Indonesia di kancah nasional dan internasional, melalui penyiaran peristiwa yang berskala internasional, dan meningkatkan kehidupan masyarakat, serta menjadi alat yang dapat mempersatukan keberagaman. Itu berarti TVRI menjadi alat komunikasi pemerintah dalam menyampaikan informasi tentang kebijakan pemerintah kepada rakyat pada waktu yang bersamaan.

Setiap lembaga penyiaran di Indonesia memiliki tanggung jawab sosial yang sama. Asas, Tujuan, Fungsi, dan Arah lembaga penyiaran di Indonesia tertuang dalam UU No 32 Tahun 2002 Tentang Penyiaran. Pasal 2 UU tersebut menyatakan, "Penyiaran diselenggarakan berdasarkan Pancasila dan Undang-Undang Dasar Negara Republik Indonesia Tahun 1945 dengan asas manfaat, adil dan merata, kepastian hukum, keamanan, keberagaman, kemitraan, etika, kemandirian, kebebasan, dan tanggung jawab." Kemudian, di Pasal 3 menegaskan, 
"Penyiaran diselenggarakan dengan tujuan untuk memperkukuh integrasi nasional, terbinanya watak dan jati diri bangsa yang beriman dan bertakwa, mencerdaskan kehidupan bangsa, memajukan kesejahteraan umum, dalam rangka membangun masyarakat yang mandiri, demokratis, adil dan sejahtera, serta menumbuhkan industri penyiaran Indonesia". Adapun Pasal 4 ayat (1) UU tersebut berbunyi, "Penyiaran sebagai kegiatan komunikasi massa mempunyai fungsi sebagai media informasi, pendidikan, hiburan yang sehat, kontrol dan perekat sosial."

Sebagai lembaga penyiaran publik yang dana pengelolaannya ditanggung oleh APBN (Anggaran Pendapatan dan Belanja Nasional) yang merupakan uang rakyat, keberadaan TVRI dituntut agar lebih optimal mengimplementasi prinsip-prinsip tanggung sosial sesuai amanat undang- undang. TVRI bertugas melayani kepentingan publik, sebagai media informasi, media pendidikan, media hiburan yang sehat, serta media kontrol dan perekat sosial.

\section{METODE}

Dalam penelitian ini, penulis hanya berfokus pada bentuk-bentuk implementasi teori pers tanggung jawab sosial yang dijalankan dalam pemberitaan. Teknik pengumpulan data yang digunakan yaitu observasi, wawancara dan dokumentasi. Teori yang dipakai dalam penelitian ini ada Teori Tanggung Jawab Sosial Pers, dan konsep yang digunakan adalah media massa, televisi, dan TVRI sebagai lemnaga layanan publik.

Penelitian kualitatif cenderung bersifat deskriptif, naturalistik, dan berhubungan dengan sifat data yang murni kualitatif maka dari itu, jenis penelitian ini adalah deskriptif karena berusaha untuk memberikan gambaran/penjelasan dengan menggunakan kata-kata, serta menyajikan profil (persoalan), klasifikasi jenis, atau garis besar tahapan (Neuman, 2013:44). Peneliti juga akan mendapatkan gambaran yang lebih jelas dan lebih rinci dari data yang ditemukan melalui wawancara, observasi dan dokumentasi mengenai prinsipprinsip tanggung jawab sosial pers yang diterapkan di lembaga penyiaran publik TVRI.

\section{HASIL DAN PEMBAHASAN}

Stasiun televisi yang ditetapkan sebagai lembaga penyiaran publik jelas diatur dalam Pasal 14 ayat (2) UU Penyiaran, di dalam UU tersebut jugamenetapkan bahwa LPP terdiri atas TVRI dan RRI.Seperti yang diketahui bahwa LPP adalah lembaga penyiaran yang berbentuk badan hukum yang didirikan oleh negara, bersifat independen, netral, tidak komersial, dan berfungsi memberikan layanan untuk kepentingan masyarakat. Sebagai sebuah lembaga penyiaran TVRI bertanggung jawab penuh terhadap kepentingan publik atau masyarakat.

Kehadiran TVRI sebagai Lembaga Layanan Publik berupaya untuk mengedepankan unsur informasi, pendidikan, hiburan yang sehat, serta kontrol sosial di dalam setiap kontennya. Oleh sebab itu, tidaklah heran jika TVRI masih menjadi stasiun televisi rujukan bagi sebagian masyarakat yang mampu memberikan pengaruh positif melalui tayangannya, karena TVRI yang tidak fokus akan rating namun lebih fokus kepada kebutuhan masyarakat.

Sejak mengudara sampai sekarang TVRI selalu berupaya untuk menjalankan tanggungjawab sosial kepada masyarakat. Bentuk tanggung jawab sosial yang dilakukan oleh TVRI dapat dilihat dari sejauh mana TVRI memandang tanggung jawab itu sebagai sesuatu hal yang sangat penting dan harus dijalankan dengan sungguh-sungguh. Seperti yang kita tahu tanggung jawab sosial ini melibatkan pers, publik, dan pemerintah di mana pemerintah membangun LPP untuk membantu menghubungkan antara masyarakat dengan pemerintah.

Jika mengulik kembali kisah TVRI di zaman pemerintahan Soeharto bisa dirasakan sekali bahwa TVRI belum menerima dan memenuhi kewajiban kepada masyarakat. TVRI masih digunakan untuk alatnya pemerintahan setiap tayangan bahkan pemberitaannya pun masih di tujukan untuk kepentingan pemerintahan pada saat itu.

Pemberitaan yang ditampilkan pada masa jabatan Soeharto, yaitu: Laporan khusus pengumuman kabinet pembangunan $\mathrm{V}$, Temu wicara Pak Harto dengan Nelayan Jakarta, Peresmian Proyek Nusa Tenggara, Soeharto Mengantar Indonesia ke Swasembada pangan. Bahkan kebijakan yang di buat oleh Soeharto pada saat itu di mana tv swasta juga diwajibkan menampilkan laporan khusus Soeharto. Ini yang menuai pro dan kontra karena saat masyarakat sedang menikmati tayangan mereka seketika akan diganti dengan tayangan laporan khusus Soeharto. Namun semenjak Soeharto, turun dari jabatannya kebijakan itu pun menghilang tv 
swasta akhirnya bisa menyiarkan tayangan mereka tanpa harus ada laporan khusus.

Di zaman pemerintahan Susilo Bambang Yudhoyono, salah satu contoh kasus di mana TVRI melanggar asas netralisasi dan independensi adalah ketika menayangkan konvesi partai Demokrat di tahun 2013 silam. Pada saat itu acara konvensi disiarkan dengan durasi yang cukup lama yaitu 2 jam lebih, dan pada saat itu juga TVRI tidak memberikan kesempatan yang sama kepada partai lain.

TVRI sebagai televisi publik harusnya memberikan tayangan yang menyiarkan tayangan yang bermanfaat bagi kepentingan publik. Moment di mana TVRI menyiarkan konvensi partai Demokrat selama 2 jam lebih menandakan ada beberapa pelanggaran terkait siaran publik pertama TVRI TVRI tidak memberikan tayangan yang berpihak kepada publik, tayangan TVRI di tujukan kepada kepentingan partai politik, dan dalam sisi lain TVRI berusaha untuk mencari aman tidak ingin bermasalah dengan pemerintah.

Memanfaatkan kebebasan pers yang diberikan, yaitu kebebasan berkomunikasi dan berekspresi dalam memberikan informasi kepada publik melalui setiap program acara di televisi. Bahkan terterah di dalam UU 1945 pasal 28 F yang jelas menjabarkan kegiatan pers yaitu "berhak untuk mencari, memperoleh, memiliki, menyimpan, mengolah, dan menyampaikan informasi dengan menggunakan segala jenis saluran yang tersedia. Bentuk dari pengimplementasian tanggung jawab itu dilakukan dengan menerima dan memenuhi kewajiban kepada masyarakat. Sebagai lembaga layanan publik, TVRI sudah sepatutnya menjamin kebutuhan masyarakat akan informasi terkait penyiaran berita yang objektif dan akuntabilitas.

TVRI dengan kondisi-kodnisi yang ada, sulit dan tidak akan bisa menjalankan fungsi, peran dan posisinya sebagai LPP sebagai mana mestinya. Penemuan yang di dapat masih mendominasi penjelasan bahwa sejauh ini TVRI belum mampu memenuhi kewajiban dalam masyarakat.

TVRI masih mengekor dari televisi swasta, akhirnya yang membuat isi dari siaran TVRI bisa di katakan mirip dengan televisi swasta. Tantangan terberat yang harus di lewati oleh LPP yang membuat fungsi tidak berjalan efektif, yaitu: adanya masalah dengan pembiayaan, SDM, serta organisasinya. Posisi dan misi TVRI semakin hari di perbesar tetapi daya dukungnya justru melemah. Pemasukan TVRI yang bersumber dari APBN juga menjadi salah satu faktor
TVRI akhirnya sulit untuk memposisikan diri menjadi televisi publik sesuai dengan fungsinya

Namun, TVRI masih terus berupaya melepaskan diri dari pengaruh orde baru, dan membenahi lembaganya. Berusaha menjalankan kewajibannya kepada masyarakat dengan selalu konsisten menyajikan informasi melalui program berita dan program lainnya setiap hari dengan tetap mengacu pada kebutuhan masyarakat. Serta berusaha menjadikan lembaga layanan publik ini sebagai televisi referensi yang mampu memberikan sumber hiburan yang sehat, sebagai media pendidikan bagi penonton atau publik diharapkan setiap informasi yang disiarkan oleh TVRI harus bisa mencerdaskan masyarakat dan tidak membuat publik bingung lewat pemberitaan informasi bohong yang beredar di sekitar lingkungan masyarakat.

Sebuah kewajiban sebagai media penyiaran publik yang harus dilakukan dengan profesionalitas mengenai informasi, kebenaran dari sebuah informasi, ketepatannya, objektivitas, dan juga keseimbangan. Pers dalam bekerja harus bebas berekspresi berani mengeluarkan pendapat tanpa ada tekanan dalam menyajikan sebuah berita yang seharusnya, pers juga perlu ketelitian, berita yang disajikan oleh pers harus bisa memberikan pencerahan dalam artian berita yang dipublikasi harus benar-benar objektif dan akuntabilitas sehingga publik mendapatkan jaminan memperoleh informasi sesuai fakta.

Sejauh ini TVRI mulai melakukan perbaikan. Namun, dalam melakukan perbaikan itu masih ditemukan kendala-kendala. Hal ini, yang menyebabkan upaya perbaikan itu tidaklah mudah. TVRI sedang berupaya melepaskan diri dari beban masa lalu. Uang yang dimiliki TVRI sudah cukup banyak, TVRI sudah harus mulai mengatur, namun sampai sekarang belum ada usaha dari TVRI untuk memperjuangkan itu dan perlu juga merubah pola pikir TVRI jika ingin lebih baik.

Seperti yang dikemukakan oleh McQuail (2010: 167) bahwa tingkat kebebasan informasi yang terjadi dalam suatu negara dapat dilihat dari kebebasan untuk menyampaikan dan menyiarkan informasi, bebas dari tekanan ekonomi politik, memberikan kesempatan yang luas kepada masyarakat dalam menyampaikan aspirasi dan memperoleh informasi, bagi para penerima berita, sesuai kriteria: relevan, beragam, menarik, reliabel, orisinil dan memuaskan. 
Namun berdasarkan penemuan, dalam melakukan tangggung jawab ini TVRI secara keakuratan berita sudah tepat, akurat, dan berimbang. Namun jika menyinggung keberimbangan yang berhubungan dengan permasalahan yang terjadi antara masyarakat dan pemerintahan TVRI sebagai lembaga layanan publik dianggap belum sepenuhnya menyajikan informasi yang benar-benar berimbang, posisi TVRI yang berat sebelah hal ini karena dipengaruhi oleh faktor di mana pemerintah yang menyetujui anggaran TVRI seperti yang sudah di jelaskan di atas.

Jika dibandingkan dengan penelitian yang dilakukan oleh Iwan Suhatno (2009), pada media cetak "Harian Pekan Baru Pos" bagaimana pers membantu pemerintah untuk melakukan pembangunan kepada masyarakat secara merata. Pekanbaru Pos selalu menyajikan berita yang berimbang dan tidak dicampuri oleh kepentingan dari pihak mana pun benar- benar mengkritik dan memberikan hak jawab apabila dimintai. Untuk memperoleh cara profesional dalam melaksanakan tugas, setiap wartawan Pekanbaru Pos tetap berpegang teguh pada etika profesi wartawan yang mengikat yaitu kode etik jurnalistik.

Selain itu, wartawan menganggap profesionalisme kerja dapat dilihat dari kedisiplinan seluruh anggota pekerja pers terhadap absensi, menghadiri setiap rapat, dan juga mematuhi semua aturan yang berlaku. Wartawan Pekanbaru Pos juga benar-benar menulis fakta yang ada, dan informasi yang disampaikan memang merupakan informasi yang sebenarnya dan bukan rekayasa. Wartawan Pekanbaru Pos berpendapat bahwa menulis itu sama halnya dengan mendidik, sehingga Pekanbaru Pos itu berperan mendidik bangsa melalui tulisan, selain itu wartawan menulis berita apa adanya sesuai dengan fakta dan sesuai dengan undangundang pers serta kode etik jurnalistik.

Namun berdasarkan penemuan di lapangan yang menyangkut kedisiplinan tenaga kerja TVRI masih kurang disiplin, masih kurang kesadaran dalam ketepatan waktu kerja dan juga dalam melihat dari segi konten pemberitaaannya TVRI masih belum berimbang karena lebih dominan pemberitaan menyangkut kepentingan pemerintah ketimbang menjaga keseimbangan sebagai TVRI lembaga layanan publik. Dalam pemberitaan kemajuan pembangunan infrastruktur, misalnya, TVRI hanya menyajikan pencapaian pemerintah tapi tidak memberikan porsi bagi masukan atau kritik dari masyarakat terhadap proses pembangunan.
Penelitian yang dilakukan Ghasanni \& Sukowati (2016) juga menjelaskan hubungan segitiga yang terjadi antara pers, masyarakat, dan pemerintah di mana pers berperan sebagai jembatan penghubung antara pemerintah dengan masyarakat namun pada kenyataan hubungan tersebut belum tercermin hubungan yang ideal mengapa demikian, karena masih terjadi kapitalisme media, masih ada intervensi politik, bahkan ada juga kedekatan wartawan dengan pejabat sehingga membuat wartawan menjadi subjektif. Ini juga yang menjadi hambatannya untuk memberikan berita yang kredibel dan dapat dipercaya. Seperti yang diketahui bahwa seharusnya ruang publik itu bersifat bebas, terbuka, transparan dan tidak ada intervensi dari pemerintah, kaum pemilik modal, kelompok kepentingan, maupun pemasang iklan di dalamnya (McQuail, 2010: 181).

Bentuk tanggung jawab sosial dari sebuah lembaga layanan publik adalah harus mandiri dalam mengelolah lembaganya sendiri, seperti yang disampaikan oleh McQuail bahwa lembaga penyiaran publik merujuk kepada sistem yang dibentuk oleh hukum dan umumnya juga dibiayai oleh dana publik, dan diberikan keleluasan editorial dan kinerja yang mandiri (2010: 196). Dari penjelasan McQuail dapat disimpulkan bahwa walaupun lembaga penyiaran publik dibangun oleh negara dan dibiayai oleh dana publik, pemerintah yang menetapkan badan pekerjanya namun negara menyerahkan sepenuhnya kepada media untuk mengelolah sendiri.

Realitanya yang terjadi kepada lembaga penyiaran publik di Indonesia seperti TVRI dalam mengelolah lembaganya masih dapat dikatakan belum mandiri karena TVRI sejauh ini mengandalkan pendapatan dari APBN saja dan tidak mengusahakan sendiri, hal ini juga dipengaruhi oleh kebijakan dari pemerintah yang membatasi periklanan TVRI hanya diperbolehkan memasang iklan layanan masyarakat yang di mana TVRI tidak mendapatkan bayaran dari pemasangan iklan tersebut karena dianggap sebagai tv negara. TVRI juga sangat bergantung kepada peraturan yang dibuat oleh pemerintah, TVRI juga harus patuh terhadap aturan yang dibuat pemerintah karena pemerintahlah yang menyetujui nominal anggaran untuk TVRI. TVRI belum bisa mandiri dalam arti secara keseluruhan independen, karena anggarannya masih berasal dari negara, di dalamnya pemerintah yang menyetujui anggaran, yang membuat pemerintah punya akses untuk 
intervensi TVRI. Tenaga kerja TVRI mayoritasnya masih PNS dan SDM TVRI masih di bawah pengawasan Kementrian Komunikasi dan Informasi.

TVRI sebagai lembaga penyiaran publik bukan saja memenuhi kebutuhan masyarakat akan informasi namun TVRI juga harus turut terlibat dalam membangun negeri tercinta. Sesuai dengan hastag TVRI sebagai televisi pemersatu bangsa TVRI dianggap sebagai agent pembangunan dan penyeimbang penyampaian informasi kepada masyarakat. Segala upaya sudah dilakukan TVRI begitu juga dalam pemberitaan yang berusaha menghindari konten-konten yang dapat memecah belah persatuan dan kesatuan, menimbulkan kejahatan yang dapat merugikan masyarakat.

Sebagai lembaga layanan publik, TVRI memiliki prinsip setiap kontennya dapat memberikan pencerahan serta pengetahuan bagi masyarakat. Menjalankan peran sebagai media informasi yaitu dengan memberikan informasi yang tidak berbau hoax, berita yang disajikan tidak mengandung unsur SARA, atau menjatuhkan sekelompok masyarakat. TVRI sudah menjaga posisi sebagai televisi pemersatu bangsa, namun belum bisa efektif. TVRI seharusnya muncul sebagai leader, jika mau mempersatu bangsa, yang sekarang harus muncul di layar televisi adalah bagaimana TVRI mencari aman bukan sebagai agent pemersatu. Artinya TVRI tidak ingin mengulas tentang berita-berita yang kontroversi.

Sebagai lembaga layanan publik, TVRI juga terbuka kepada masyarakat dengan memberikan kesempatan bagi masyarakat untuk turut mengontrol kinerja TVRI, membagikan sudut pandang mereka, ide dan gagasan yang mereka punya dengan melibatkan masyarakat untuk turut berpartisipasi memberikan informasi dalam program berita jurnalisme khalayak, mengintropeksi kesalahan-kesalahan yang dilakukan oleh TVRI selama menjalankan tugas. Semua itu dilakukan untuk meningkatkan kredibilitas TVRI yang lebih baik, dan bermafaat juga bagi masyarakat untuk mengajarkan masyarakat lebih peka dengan lingkungan sekitar dan juga bentuk dari tanggung jawab sosial.

Namun tanggung jawab ini tidak dapat dijalankan dengan mudah karena ada kendalan yang harus dihadapai, kadang-kadang masyarakat memiliki tingkat kedewasaan yang masih kurang, sehingga menjadi hambatan untuk mencari narasumber maka dari itu harus bisa diseleksi lagi narasumber yang dirasa tepat sesuai dengan informasi yang dibutuhkan, dan juga banyak sekali beredar berita hoax sehingga TVRI harus benar-benar lebih selektif lagi memilih berita yang akan ditayangkan.

Lembaga layanan publik memusatkan perhatiannya kepada kepentingan masyarakat, untuk itu masyarakat juga memiliki hak untuk mengharapkan standar prestasi yang tinggi dari pers dalam arti hak-hak masyarakat dilakukan dengan penuh rasa tanggung jawab tidak asalasalan sehingga masyarakat juga merasa puas dan kontrol masyarakat dalam hal ini dibenarkan untuk mengamankan kepentingan bersama, sehingga masyarakat berhak untuk melaporkan adanya dugaan kelalaian yang dilakukan oleh pers dalam mempublikasikan berita kepada masyatrakat, atau mengkritik kinerja dari pers ini sebagai bentuk kerjasama yang untuk membangun kredibilitas pers yang lebih baik lagi. Secara regulasi, masyarakat dapat memantau kinerja TVRI secara langsung melalui Dewan Pengawas dan interaksi langsung melalui medium yang disediakan.

Menurut penelitian yang dilakukan Ghasanni \& Sukowati (2016) dalam penelitannya menjelaskan dalam hal ini media massa dikontrol pemanfaatannya oleh masyarakat bahkan oleh kelompok minoritas sekalipun, masyarakat mempunyai kesempatan yang sama dalam rangka mengutarakan pendapatnya apabila ada sesuatu atau isu tertentu. Salah satu ciri dari tanggung jawab sosial media ini adalah bahwa media massa boleh dimiliki oleh swasta untuk mencari keuntungan, akan tetapi media massa atau pers harus berfungsi untuk kepentingan umum atau kesejahteraan umum. Apabila pers gagal melakukan fungsinya tersebut maka masyarakat berhak menuntut dan meluruskannya.

Sebagai Lembaga layanan publik TVRI berupaya menjalankan tugasnya sebagai media informasi kepada masyarakat, di mana melalui tayangan-tayang TVRI disitu publik mendapatkan informasi yang berfaedah, jika melihat dari status TVRI sebagai lembaga penyiaran publik dalam setiap konten TVRI bukan hanya mengandung unsur informasi namun juga terdapat unsur pendidikan juga dianggap penting untuk menambah pengetahuan publik. Diharapkan melalui pemberitaan publik juga mendapatkan pendidikan, dengan pemberitaan menggunakan bahasa Indonesia yang baik dan benar juga sangat membantu penonton belajar bagaimana berbahasa Indonesia yang baik dan benar. Hal ini juga 
sebagai bukti untuk media penyiaran lain bahwa penggunaan bahasa Indonesia yang baik dan benar itu ada di berita-berita TVRI.

Memegang peranan sebagai lembaga layanan yang memberikan hiburan melalui konten hiburan. Bentuk hiburan itu bisa berasal dari cara orang menyampaikan sesuatu yang dapat membuat merasa terhibur untuk itu hiburan yang dimaksudkan oleh TVRI lebih kepada menampilkan seni dan budaya dengan kearifan lokal dari negara Indonesia yang ditampilkan dalam documenter, dan features. Sesuai dengan pernyataan dari Morissa bahwa hiburan itu dapat berupa segala bentuk siaran yang bertujuan untuk menghibur audien (Morissan, 2009: 200).

Bukan itu saja fungsi media televisi sebagai media kontrol dan perekat sosial sesuai dengan TVRI sudah dirangkum sebelumnya, kesadaran akan keberadaannya sebagai stasiun televisi pemersatu bangsa membuat TVRI enggan menutup diri dari kondisi yang alami oleh bangsa ini, dengan komitmen bersama untuk membangun bangsa ini yang direalisasikan dalam siaran yang berupaya memberikan pengaruh positif, siaran yang benarbenar menjauhi masyarakat dari ancaman hoax yang beredar, atau konten-konten yang dapat menyinggung sekelompok etnis. Seperti yang diketahui bahwa tayangan memiliki pengaruh yang besar kepada khalayak, pengaruh itu bisa berdampak positif bahkan juga negatif sehingga perlu selektif dalam memberikan informasi yang tidak memberikan pengaruh buruk kepada masyarakat.

TVRI berusaha untuk melakukan kontrol sosial dengan tidak selalu menyajikan berita-berita yang mengandung unsur kriminal, TVRI menganggap bahwa konten yang mengandung unsur kriminal tidaklah baik dapat membawa pengaruh buruk dan memberikan contoh negatif bagi penonton dan apabila berita kriminal disiarkan secara nasional dapat membentuk persepsi negara lain bahwa negara Indonesia sangatlah rawan kriminal sehingga TVRI lebih memilih untuk tidak menyajikan beritaberita kriminal setiap harinya seperti yang dilakukan oleh televisi swasta, TVRI hanya akan menampilkan berita kriminal yang bersifat nasional, selain dari pada itu kasus-kasus yang bersifat sementara tidak ditampilkan oleh TVRI.

\section{SIMPULAN}

Televisi Republik Indonesia sebagai salah satu lembaga penyiaran publik yang dibangun oleh negara yang bertugas untuk membantu pembangunan bangsa, melalui setiap penyiarannya, TVRI belum mampu menjalankan tanggung jawab sosial sebagaiman fungsinya sebagai lembaga penyiaran publik. Namun, TVRI berusaha untuk membenahi lembaga dan keluar dari pengaruh orde baru. Upaya TVRI melakukan tanggung jawab kepada masyarakat dengan selalu menjalankan fungsinya sebagai media hiburan, media informasi, media perekat sosial, dan media pendidikan sesuai dengan yang tercantum dalam UU penyiaran tidak mudah. Hal ini, dikarenakan pengelolaan TVRI yang tidak maksimal, dan budaya kerja yang masih mengikuti budaya PNS yang akhirnya membuat TVRI sulit untuk bersaing dengan televisi swasta

TVRI menjadi stasiun televisi rujukan bagi masyarakat yang mampu memberikan pengaruh positif melalui tayangannya dan TVRI juga tidak berfokus akan rating namun lebih fokus kepada apa yang menjadi kebutuhan masyarakat. TVRI melihat secara umum hal-hal penting yang tidak diberikan oleh televisi komersial disitu TVRI hadir untuk memenuhi itu. Namun, TVRI masih belum mampu melepaskan diri dari tekanan dari pemerintah.

Sejauh ini belum terlihat upaya TVRI menerima dan menjalankan kewajiban kepada masyarakat sebagai bentuk tanggung jawabnya secara independen, TVRI hanya fokus dengan selalu konsisten menyediakan konten-konten yang beragam dan dapat menjadi sumber hiburan yang sehat.

Jika berbicara mengenai kewajiban yang dilakukan lembaga penyiaran publik atas dasar profesionalitas sehingga dapat menjamin informasi yang siarkan, kebenaran dari sebuah informasi, ketepatannya, objektivitas, namun disela-sela itu TVRI juga harus profesional dalam mengabdi kepada masyarakat membenahi keredaksiannya harus lebih bekerja extra untuk menyajikan berita yang benar-benar berimbang dan netral tidak berpihak sehingga TVRI dapat dipercaya keinformasiannya. TVRI juga harus bersikap netral menanggapi kasus-kasus kontroversi yang menimpa bangsa.

Secara jelas bentuk tanggung jawab lembaga penyiaran publik adalah mampu mengelolah lembaga secara mandiri namun bertolak belakang dengan fenomena yang dialami oleh TVRI sendiri, sejauh ini TVRI masih bergantung kepada kebijakan 
yang dibuat pemerintah dan APBN sebagai pendapatan mereka. Sehingga upaya TVRI dalam menyajikan konten-konten yang berkualitas dan berdaya saing masih sulit dilakukan hal ini karena kebijakan yang menghalangi.

\section{DAFTAR PUSTAKA}

AL-Ahmed, M. (1987).The six Normative Theories and the role of Social, Political and Economicforces in shaping Media Institutions and Content: Saudi Arabia-a Case Skristudy.

Desakan TVRI Layani Publik di antara Gelombang Media yang Partisa. Diakses pada 12 Agustus 2018, dari https://tirto.id/desakan-tvri-layanipublik-di-antara-gelombang-media-yangpartisan-cG14.

Ghassani, V. I., \& Sukowati, P. (2016). Bentuk Hubungan Pers dengan Pemerintahan Terkait Dengan Fungsi Media sebagai Kontrol Sosial. Jurnal Interaksi, Vol 1 No.2. Diakses di http:// jurnal.unmer.ac.id/index.php/jkpp/article/ view/502.

Hutagalung, I. (2013). Dinamika sistem pers di Indonesia. Jurnal Interaksi, Vol II No.2. Diakses di https://ejournal.undip.ac.id/index.php/ interaksi/article/view/6588.

Hanretty, C. (2011). Public Broadcasting and Political Interference. New York: Routledge.

McQuail, D.(2010). McQuaill Mass Communication Theory. London: Sage Publication.

Morissan. (2009). Manajemen Media Penyiaran: Strategi Mengelola Radio \& Televisi. Jakarta: Kencana Prenada Media Group.

Sejarah TVRI. Diakses pada 12 Agustus 2018, dari tvri.co.id https://www.tvri.co.id/page/sejarah.

Siebert, F., et. al. (1986). Empat Teori Pers. Jakarta: Intermasa.

Soerjokanto. (2003). Definisi Televisi. Jakarta: PT Gramedia.

Suhatno, I. (2009). Penerapan Kebebasan Pers dalam Perspektif Etika Profesi Wartawan (Studi Deskriptif Pada Harian Pekanbaru Pos). Universitas Islam Negeri Sultan Syarif Kasim Riau. Skripsi tidak diterbitkan.

Teguran Tertulis untuk Program Siaran Jurnalistik "Indonesia Hari Ini" TVRI. Diakses pada 10 Agustus 2018, dari kpi.go.id:https://www.kpi. go.id/index.php/id/edaran-dan-sanksi/34643- teguran tertulis-untuk-program-siaranjurnalistik-indonesia-hari-ini-tvri.

TVRI di hukum, TV Swasta di biarkan. Diakses pada 12, Agustus 2018, dari https://nasional.tempo. co/read/515384/tvri-dihukum-tv-swastadibiarkan.

UU Penyiaran No.32 tahun 2002tentang Penyiaran. UU Pers No.40 tahun1999 tentang Pers. 